\title{
miR-520e regulates cell proliferation, apoptosis and migration in breast cancer
}

\author{
MING YI ${ }^{1,2}$, MINGHUA LI $^{1}$, XIA LONG $^{1}$, JING YE $^{1}$, JUNWEI CUI $^{1}$, WEI WEI ${ }^{1}$, HUIJUAN WAN ${ }^{1}$, \\ MEIJUN YIN ${ }^{1}$, SHUYING GAO ${ }^{3}$, ZHENGMING SU ${ }^{1,2}$ and FANGTING ZHANG ${ }^{1}$ \\ ${ }^{1}$ Central Laboratory, Peking University Shenzhen Hospital, Shenzhen, Guangdong 518036; \\ ${ }^{2}$ Department of Graduate Studies, Shantou University Medical College, Shantou, Guangdong 515041; \\ ${ }^{3}$ Department of Biochemistry and Molecular Biology, Zhuhai Campus Zunyi \\ Medical University, Zhuhai, Guangdong 519041, P.R. China
}

Received January 7, 2015; Accepted September 24, 2015

DOI: $10.3892 / \mathrm{ol} .2016 .5085$

\begin{abstract}
Previous studies have indicated that the deregulation of microRNAs contributes to tumorigenesis. Misregulation of microRNA-520e (miR-520e) has been observed in various types of cancer. However, the expression profile and biological function of miR-520e in breast cancer remains largely unknown. The present study demonstrated that miR-520e expression was significantly increased in breast cancer tissues compared with adjacent non-cancerous breast tissues in 21 patients, as revealed by reverse transcription-quantitative polymerase chain reaction. Furthermore, the proliferation capacity of breast cancer cells was markedly enhanced by the introduction of miR-520e in vitro using a cell counting kit- 8 assay. The present study also revealed that the overexpression of miR-520e could suppress breast cancer cell apoptosis, revealed using Annexin V/propidium iodide double staining and flow cytometry analysis. In addition, the ectopic expression of miR-520e promoted the migration of breast cancer cells in vitro, as demonstrated by a Transwell assay. Overall, the findings of the present study highlight an important role for miR-520e in breast cancer development and in the molecular etiology of breast cancer, which indicates the potential application of miR-520e in cancer therapy.
\end{abstract}

\section{Introduction}

Previous studies have demonstrated that alterations in protein-coding genes are critical for the development of human cancer $(1,2)$. Other studies have indicated that deregulation of

Correspondence to: Miss. Fangting Zhang, Central Laboratory, Peking University Shenzhen Hospital, 1120 Lian Hua Road, Shenzhen, Guangdong 518036, P.R China

E-mail: fangtingzhang@126.com

Key words: miRNA-520e, proliferation, apoptosis, migration, breast cancer non-coding genes, particularly microRNAs (miRNAs), also contribute to tumorigenesis (3-6).

miRNAs belong to a class of phylogenetically conserved non-coding RNAs that regulate an abundance of cellular processes by binding to specific target messenger RNAs (7). Numerous studies indicate that miRNAs are important in various biological processes, including the cell cycle, development, cell proliferation, differentiation and apoptosis (8-12). More than half of the miRNA genes are located in chromosomes that have been observed to become amplified, deleted or translocated during the development of cancer (13). In addition, deregulation of specific miRNAs occurs in certain cancer types $(14,15)$, and this has been suggested to be associated with the prognosis of cancer patients (16). Furthermore, a previous study proposed that miRNAs may act as oncogenes or tumor suppressor genes (6). These findings highlight the importance of miRNAs in cancer development and provide insight into the molecular mechanisms that cause tumorigenesis.

Globally, breast cancer is the most common cause of cancer-associated mortality in women, and accounted for $\sim 1.38$ million novel cases and 458,000 mortalities in 2008 (17). As with other solid tumors, multiple genetic and epigenetic alterations in protein-coding genes have been observed in breast cancer (18). However, previous findings alone cannot explain the complexity of breast cancer. Previous studies have demonstrated that dysfunction of miRNAs contributes to breast cancer development $(11,14)$. Zhang et al reported that microRNA-520e (miR-520e) was associated with hepatocarcinogenesis (19); however, the biological significance of miR-520e in breast cancer remains largely unknown. The present study demonstrated that miR-520e is upregulated in breast cancer tissues and promotes proliferation, invasion and migration, and inhibits the apoptosis of cancer cells. The results of the present study suggest that miR-520e may be an attractive target for cancer therapy.

\section{Materials and methods}

Human tissue specimens. The present study was approved by the Institutional Review Board and Ethical Committee of Peking University Shenzhen Hospital (Shenzhen, Guangdong, 
China). All patients provided written informed consent prior to the study. In total, 21 paired breast cancer and adjacent non-cancerous breast tissues were obtained from patients that had undergone resection for breast cancer. The patient characteristics are reported in Table I. The patients had no previous local or systemic treatment prior to resection. No anticancer therapy was administered to the patients prior to relapse. The tissue samples were collected between 2012 and 2013 at the Peking University Shenzhen Hospital, and were snap frozen in liquid nitrogen and stored at $-80^{\circ} \mathrm{C}$ until required. Tumor and non-cancerous tissue samples were confirmed by histology. The histological grade was determined based on the modified Scarff-Bloom-Richardson grading system (20).

RNA oligoribonucleotides. All RNA oligoribonucleotides were purchased from Genepharma, Ltd. (Shanghai, China). miRNA duplexes corresponding to mature miR-520e were designed as previously described (21). The negative control (NC) RNA duplex for the miRNA mimic was non-homologous to any human genome sequence. The sequences were as follows: hsa-miR-520e mimic, 5'-AAAGUGCUUCCUUUU UAGGG-3'; and the hsa-miR-520e NC, 5'-UUCUCCGAACGU GUCACGUTT-3'.

Reverse transcription-quantitative polymerase chain reaction (RT-qPCR) and primers. Total RNA was extracted from tissue cells using Invitrogen TRIzol reagent (catalog no. 15596026; Thermo Fisher Scientific, Inc., Waltham, MA, USA) according to the manufacturer's protocol. cDNA was synthesized from the extracted RNA using the SYBR PrimeScript miRNA RT-PCR kit A (catalog no. RR716; Takara Biotechnology, Co., Ltd., Dalian, China). qPCR was performed with the SYBR PrimeScript miRNA RT-PCR kit B (catalog no. RR716; Takara Biotechnology, Co., Ltd.) using a LightCycler ${ }^{\circledR} 480$ Fluorescent Quantitative PCR system (Roche Diagnostics GmbH, Mannheim, Germany). Briefly, single-stranded cDNA was synthesized from $500 \mathrm{ng}$ of total RNA in a $10 \mu \mathrm{l}$ reaction volume using the SYBR PrimeScript miRNA RT-PCR kit A. The reactions were incubated at $37^{\circ} \mathrm{C}$ for $60 \mathrm{~min}$ and were then inactivated by incubation at $85^{\circ} \mathrm{C}$ for $5 \mathrm{sec}$. RT-qPCR analysis for the expression of miR-520e and the reference gene RNU6B was performed using SYBR PrimeScript miRNA RT-PCR kit B. The temperature cycle profile for the RT-qPCR reactions was as follows: $95^{\circ} \mathrm{C}$ for $30 \mathrm{sec} ; 40$ cycles of $95^{\circ} \mathrm{C}$ for $5 \mathrm{sec}$; and $60^{\circ} \mathrm{C}$ for $20 \mathrm{sec}$. To verify the specificity of the PCR product, a melting curve analysis was performed immediately subsequent to amplification, as follows: Heating to $95^{\circ} \mathrm{C}$ for $20 \mathrm{sec}$; cooling to $60^{\circ} \mathrm{C}$ for $20 \mathrm{sec}$; and heating to $95^{\circ} \mathrm{C}$ with a transition rate of $0.11^{\circ} \mathrm{C} / \mathrm{sec}$, while continuously collecting the fluorescent signal. All reactions were performed on a LightCycler 480 and were run in triplicate. The cycle quantification (Cq) values did not differ by more than 0.5 among the triplicates. The levels of target genes were normalized to the levels of the internal control genes to permit the calculation of the $2^{-\Delta \Delta \mathrm{Cq}}$ value. $\mathrm{Cq}$ is defined as the fractional cycle number at which the fluorescence passes the fixed threshold. The following primers were used: miR-520e forward, 5'-GAAAGT GCTTCCTTTTTAGGG-3' and reverse, SYBR PrimeScript miRNA RT-PCR kit universal primer; U6 forward, 5'-CTC
GCTTCGGCAGCACA-3' and reverse, 5'-ACGCTTCACGAA TTTGCGT-3' (Thermo Fisher Scientific, Inc.).

Cell culture and transfection. The human breast cancer MCF-7 and MDA-MB-231 cell lines were purchased from the American Type Culture Collection (Manassas, VA, USA). The cells lines were maintained in HyClone Dulbecco's modified Eagle's medium (DMEM; catalog no. SH30022.01B; GE Healthcare Life Sciences, Logan, UT, USA) supplemented with $10 \%$ HyClone fetal bovine serum (FBS; catalog no. 10270-106; GE Healthcare Life Sciences) and HyClone $100 \mathrm{U}$ penicillin-streptomycin (catalog no. SV30010; GE Healthcare Life Sciences) at $37^{\circ} \mathrm{C}$ in a humidified atmosphere containing $5 \% \mathrm{CO}_{2}$. RNA oligoribonucleotides were reverse transfected using Invitrogen Lipofectamine ${ }^{\circledR} 2000$ (catalog no. 11668-019; Thermo Fisher Scientific, Inc.). A final concentration of 100 nM RNA duplex was used for each transfection. The RNA transfection efficiency using this method is $\sim 90 \%$. All transfections were performed according to the manufacturer's protocol.

Assessment of cell proliferation by cell counting kit-8 (CCK-8) assay. CCK-8 assay was used to assess the proliferation of MDA-MB-231 and MCF-7 subsequent to transfection with miR-520e mimics. Briefly, MDA-MB-231 and MCF-7 cells were plated at $3.0 \times 10^{3}$ cells/well in a 96 -well plate and transfected with NC or miR-520e mimics at a final concentration of $100 \mathrm{nM}$. Prior to harvesting the cells, $100 \mu \mathrm{l}$ of spent medium was replaced with an equal volume of fresh medium containing $10 \mu 1$ CCK-8 (catalog no. CK04-500; Dojindo Molecular Technologies, Inc., Kumamoto, Japan) and incubated for $1 \mathrm{~h}$ at $37^{\circ} \mathrm{C}$. The light absorbance of each well was measured at a wavelength of $450 \mathrm{~nm}$ using an Enzyme Immunoassay Instrument (model no. 680; Bio-Rad Laboratories, Inc., Hercules, CA, USA). Each assay was repeated in triplicate.

Flow cytometric analysis of cell apoptosis. The apoptotic rate of cells was determined using Invitrogen Annexin V-fluorescein isothiocyanate (FITC) and propidium iodide (PI) double staining (catalog no. V13241; Thermo Fisher Scientific, Inc.). In total, 10,000 MCF-7 and MDA-MB-231 cells were cultured in $5 \% \mathrm{CO}_{2}$ in 6 -well plates at $37^{\circ} \mathrm{C}$. The cells were transfected with the miR-520e mimic or NC when the cells had reached $\sim 50 \%$ confluency. Subsequent to $72 \mathrm{~h}$, floating and adherent cells were collected, washed twice with PBS ( $\mathrm{pH} 7.4)$, resuspended in $100 \mu \mathrm{l}$ Annexin-binding buffer and incubated with $5 \mu \mathrm{l}$ Annexin V-FITC and $3 \mu \mathrm{l}$ PI $(50 \mu \mathrm{g} / \mathrm{ml})$. Subsequent to 20 min incubation in the dark at room temperature, $400 \mu 1$ Annexin-binding buffer was added prior to flow cytometric analysis. The samples were analyzed within $30 \mathrm{~min}$ of staining. Flow cytometry was performed using the FACSCalibur and Cell Quest software (catalog no. Navi105; Beckman Coulter, Inc., Miami, FL, USA).

Transwell migration assay. A 24-well Boyden chamber with a $8 \mu \mathrm{m}$ pore polycarbonate membrane (catalog no. 3422; Corning, Inc., Corning, NY, USA) was used to analyze the migration of MCF-7 and MDA-MB-231 cells. In total, $24 \mathrm{~h}$ subsequent to transfection with the RNA duplex, tumor cells (4x10 ${ }^{4}$ MCF-7 cells or $3 \times 10^{4}$ MDA-MB-231 cells in $200 \mu 1$ 
Table I. Clinical characteristics of 21 patients with breast cancer.

\begin{tabular}{lr} 
Characteristics & Cases, $\mathrm{n}(\%)$ \\
\hline $\begin{array}{l}\text { Age, years } \\
>50\end{array}$ & $10(47.6)$ \\
$\leq 50$ & $11(52.4)$ \\
Histological grade & \\
$>\mathrm{I}$ & $10(47.6)$ \\
$\mathrm{I}$ & $11(52.4)$ \\
Tumor size & \\
$>5$ cm & $6(28.6)$ \\
$\leq 5$ cm & $15(71.4)$ \\
Tumor number & \\
$>1$ & $10(47.6)$ \\
1 & $11(52.4)$
\end{tabular}

The histological grade was determined based on the modified Scarff-Bloom-Richardson grading system.

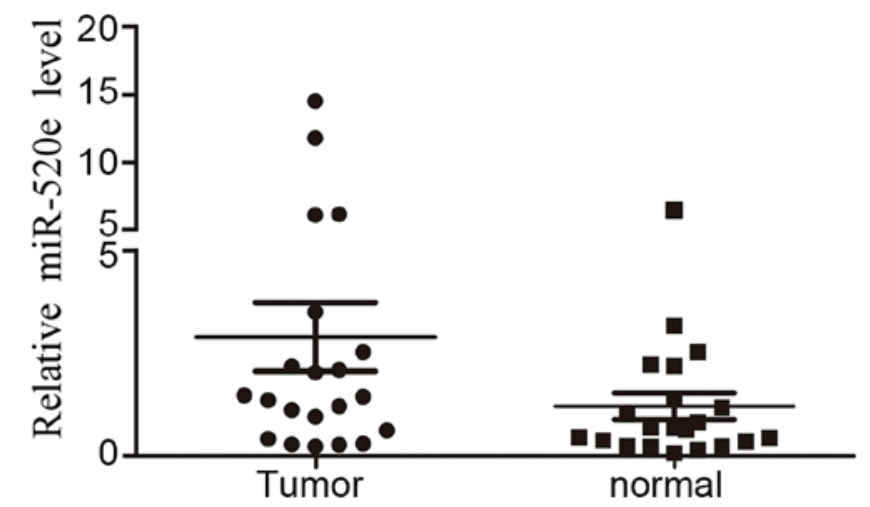

Figure 1. miR-520e expression was upregulated in BC tissues compared with adjacent non-cancerous tissues. Expression of miR-520e in $21 \mathrm{BC}$ patients was examined by reverse transcription-quantitative polymerase chain reaction and the data was normalized to the expression of a reference gene (RNU6B) to yield the relative miR-520e levels for each sample. The median level of miR-520e in all BC tissues was set as relative 1. Cases were divided into two groups on the $\mathrm{x}$ axis the $\mathrm{BC}$ (Tumor) and matched adjacent non-cancerous tissue (normal) groups. Mann-Whitney U-test was applied to compare the differences in the miR-520e expression between BC tissues and adjacent non-cancerous tissues. The horizontal line indicates the median and interquartile range ( 25 to 75 th percentiles). Data are expressed as the mean \pm standard error of the mean of 1 representative experiment $(n=3)$. Similar results were obtained in $\geq 3$ independent experiments. " $\mathrm{P}<0.05$. BC, breast cancer.

serum-free DMEM) were added to the upper compartment of the Boyden chamber, while the lower compartment was filled with $600 \mu \mathrm{l}$ DMEM containing $10 \%$ FBS. Subsequent to incubation at $37^{\circ} \mathrm{C}$ for indicated the times ( $24 \mathrm{~h}$ for MDA-MB-231, $48 \mathrm{~h}$ for $\mathrm{MCF}-7$ ), cells that had not migrated and remained on the upper surface of the polycarbonate membrane were removed with cotton swabs. The cells on the lower surface of the membrane (those that had migrated) were fixed with formaldehyde, stained with crystal violet and counted in 5 randomly selected fields of view per well, under a light microscope at a magnification of $x 150$. The cells were transfected in 3 separate transfections and each was analyzed in triplicate.

Statistical analysis. The data was expressed as the mean \pm standard error of the mean for $\geq 3$ independent experiments. Student's $t$-test was employed to analyze the significance of differences between the cancerous and non-cancerous tissue cells. For the comparison of miR-520e expression levels between the matched breast cancer and normal tissue samples, a Mann-Whitney U-test was used. All statistical tests were two-tailed and $\mathrm{P}<0.05$ was considered to indicate a statistically significant difference. All analyses were performed using SPSS software version 13.0 (SPSS, Inc., Chicago, IL, USA).

\section{Results}

miR-520e expression is upregulated in human breast cancer tissues. A RT-qPCR array was performed to analyze the expression level of miR-520e in 21 paired breast cancer and adjacent non-cancerous breast tissues. miR-520e was significantly upregulated in breast cancer tissues compared with normal tissues (Fig. 1), suggesting that miR-520e overexpression in breast cancer cells is a frequent event and that there is an association between miR-520e upregulation and breast cancer tumorigenesis.

miR-520e promotes breast cancer cell growth in vitro. The upregulation of miR-520e in breast cancer tissue samples lead the present study to investigate whether miR-520e functions as an oncogene. The effect of miR-520e restoration on the proliferation of breast cancer cells was evaluated using a CCK-8 assay on the human breast cancer MCF-7 and MDA-MB-231 cell lines, which were transfected with a control RNA duplex (NC) or miR-520e duplex. miR-520e-transfected cells exhibited an increased proliferation compared with NC transfectants (Fig. 2). These findings indicate a cell growth-promoting role for miR-520e.

miR-520e promotes breast cancer cell migration in vitro. The effect of miR-520e on breast cancer cell migration was investigated using a Transwell assay. The restoration of miR-520e substantially increased the number of MCF-7 and MDA-MB-231 cells that invaded the lower chamber in the Boyden chamber (Fig. 3).

miR-520e suppresses breast cancer cell apoptosis in vitro. The effect that miR-520e exerts on the apoptotic rate of breast cancer cells was assessed using Annexin V-FITC and PI double staining, followed by flow cytometric analysis. Fig. 4 demonstrates that the restoration of miR-520e substantially decreased the percentage of MCF-7 and MDA-MB-231 cells that underwent apoptosis. These results indicate that miR-520e inhibits the apoptosis of breast cancer cells.

\section{Discussion}

Abnormal and uncontrolled cell proliferation is a hallmark of cancer and is caused by the misregulation of various crucial proteins and alterations in miRNA expression (22). miRNAs regulate numerous biological processes, including disease 

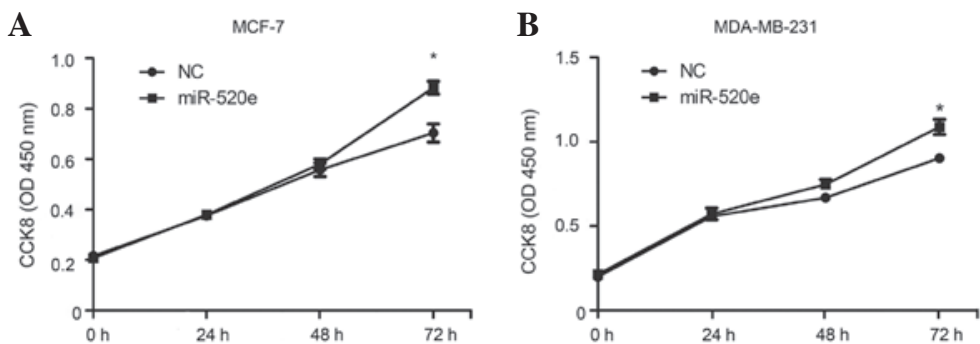

Figure 2. Overexpression of miR-520e promotes breast cancer cell proliferation in vitro. Human cell lines (A) MCF-7 and (B) MDA-MB-231 were transfected with miR-520e or NC mimics. The proliferating capacity of transfected cells was evaluated using a CCK8 assay at $0,24,48$ and $72 \mathrm{~h}$ subseuqent to transfection Data are presented as the mean \pm standard error from the mean. In 1 representative experiment $n=3$. Similar results were obtained in $\geq 3$ independent experiments. " $\mathrm{P}<0.05$. miR, microRNA; NC, negative control; CCK, cell counting kit; OD, optical density.

A

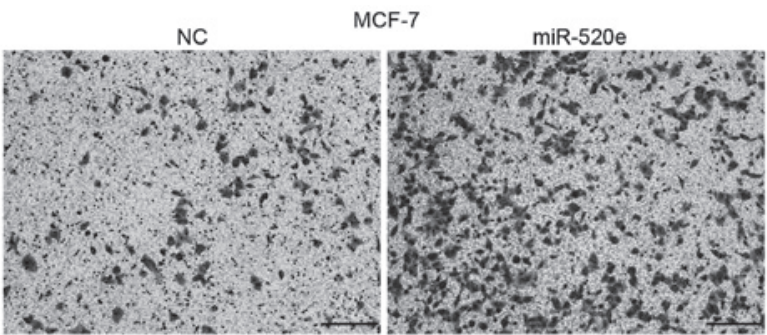

B

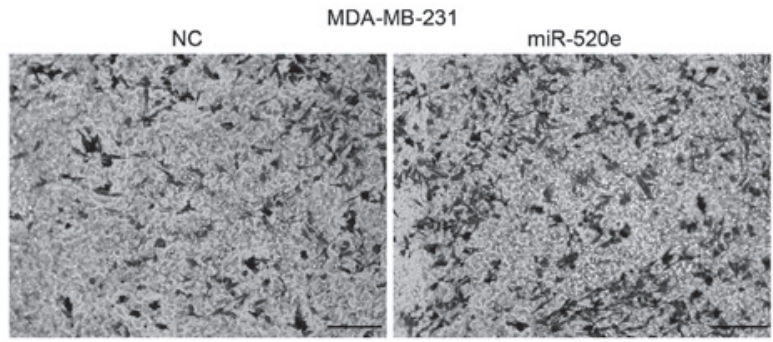

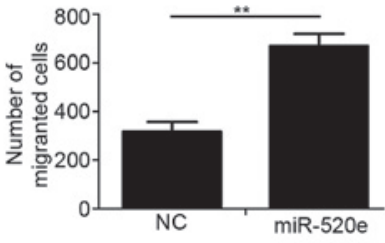

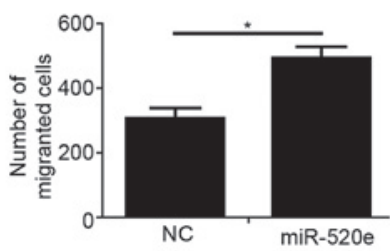

Figure 3. Restoration of miR-520e promotes breast cancer cell migration in vitro. Human cell lines (A) MCF-7 and (B) MDA-MB-231 transfected with NC or a miR-520e duplex were applied to a Boyden chamber and incubated for $24 \mathrm{~h}$ and $48 \mathrm{~h}$, respectively, followed by staining with crystal violet. The $8 \mu \mathrm{m}$ pores of the polycarbonate membranes are visible. Representative images and the number of migrated cells are shown. Similar results were obtained in $\geq 3$ independent experiments. Scale bar $=100 \mu \mathrm{m} .{ }^{*} \mathrm{P}<0.05,{ }^{* *} \mathrm{P}<0.01$. miR, microRNA; NC, negative control.
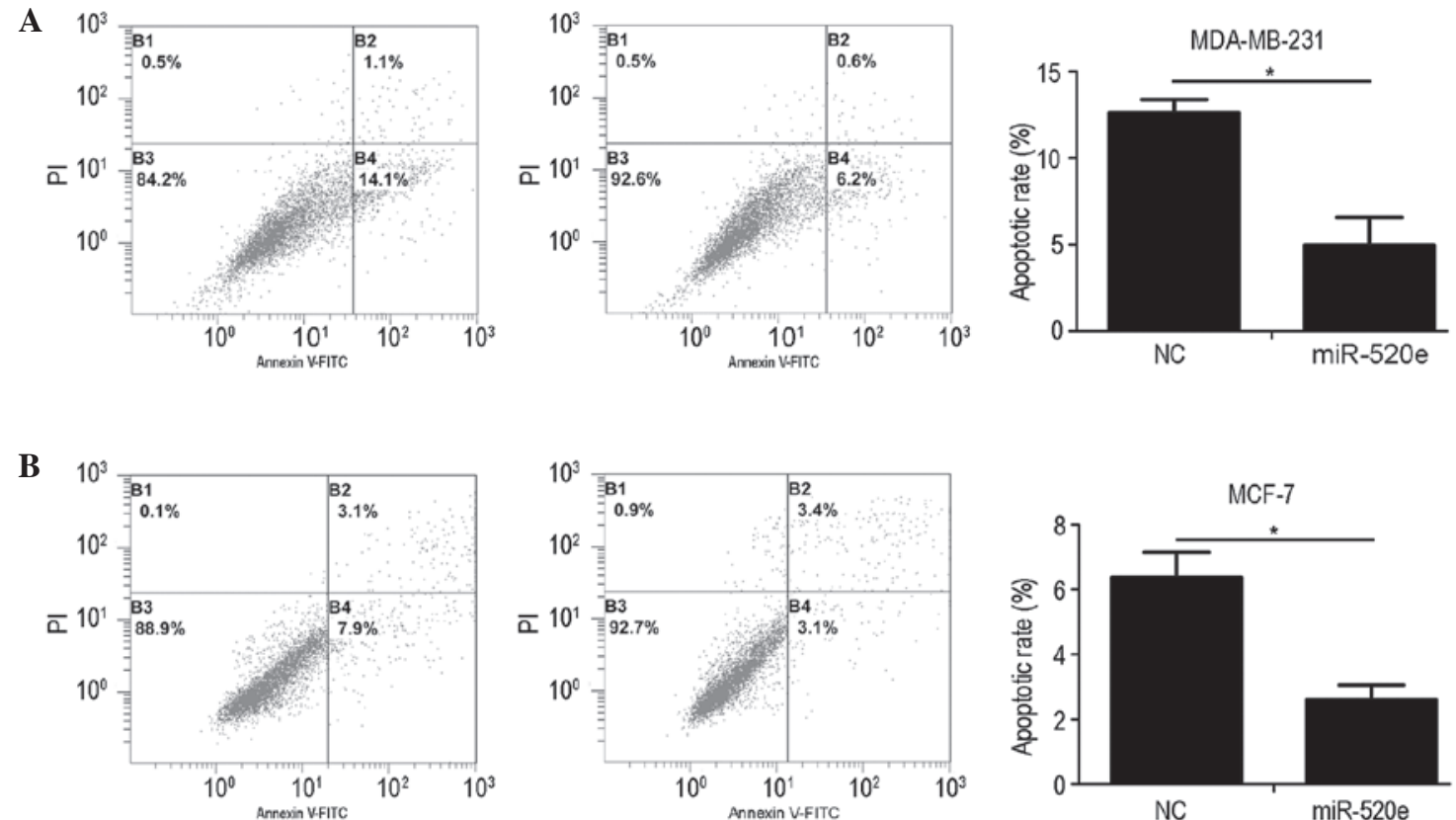

Figure 4. Ectopic expression of miR-520e inhibits breast cancer cell apoptosis. Human cell lines (A) MDA-MB-231 and (B) MCF-7 were transfected with NC or a miR-520e duplex for $72 \mathrm{~h}$. Apoptosis was analyzed using Annexin V-fluorescein isothiocyanate and propidium iodide double staining and a flow cytometer. Representative images and the apoptotic rates (\%) are shown. Similar results were obtained in $\leq 3$ independent experiments. ${ }^{*}<<0.05$. NC, negative control. 
progression and cell development, proliferation, apoptosis and differentiation (8-12). Due to the numerous biological processes that miRNAs are involved in, it is not notable that the deregulation of miRNAs has been associated with tumor progression in certain human cancers. Numerous miRNAs have been observed in breast cancer development (23-27), by functioning alone or in combination. Therefore, investigating miRNAs that are aberrantly expressed in breast cancer may aid the understanding of the mechanisms that cause breast cancer carcinogenesis and progression. The present study demonstrated that miR-520e was markedly upregulated in breast cancer tissues compared with paired adjacent normal tissues. Furthermore, the ectopic expression of miR-520e promoted breast cancer cell proliferation, migration and invasion and inhibited cell apoptosis. The current study suggests that miR-520e may act as a novel oncomir in breast cancer and may be a potential therapeutic target.

Evading cell apoptosis is crucial for the malignant transformation of a tumor and tumor progression. It aids cells to avoid immune surveillance and survive in challenging tumor environments, including those that are low in nutrition and hypoxic (28). The present study demonstrated that miR-520e could suppress the apoptosis of breast cancer cells. Therefore, the upregulation of miR-520e may facilitate the survival and development of breast cancer.

Tumor metastasis is responsible for the rapid recurrence and poor prognosis of patients; therefore, the identification of novel anti-metastasis therapeutics is imperative (29). Previous studies using clinical specimens and in vitro and in vivo models have identified a limited number of miRNAs that promote metastasis, including miR-200, miR-10b and miR-21 (30-33). The present study revealed that miR-520e is associated with metastasis; upregulation of miR-520e may facilitate the metastasis of breast cancer cells and therefore the progression of breast cancer.

In summary, the present study investigated the potential role of miR-520e in breast cancer development. The findings of the current study suggest that upregulation of miR-520e may favor malignant transformation and tumor progression of breast cancer cells, and indicate that miR-520e possesses a potential application in anti-cancer therapy.

\section{Acknowledgements}

The authors would like to thank Xiaowen Zhou and Huajian Zhong for their advice on the study and manuscript, and Xiaoqing Li and Hongfang Duan for their intellectual and technical contributions. All are graduate students at the Central Laboratory of Peking University Shenzhen Hospital. The present study was supported by grants from the Medical Scientific Research Foundation of Guangdong Province (grant no. A2011564), National Natural Science Foundation of China (grant no. 31360212), Science and Technology Development Fund Project of Shenzhen (grant no. JC201005260209A) and Science and Technology Development Fund Project of Shenzhen (grant no. JCYJ20130402114702122).

\section{References}

1. Chin K, DeVries S, Fridlyand J, Spellman PT, Roydasgupta R, Kuo WL, Lapuk A, Neve RM, Qian Z, Ryder T, et al: Genomic and transcriptional aberrations linked to breast cancer pathophysiologies. Cancer Cell 10: 529-541, 2006.
2. Stephens PJ, Tarpey PS, Davies H, Van Loo P, Greenman C, Wedge DC, Nik-Zainal S, Martin S, Varela I, Bignell GR, et al; Oslo Breast Cancer Consortium (OSBREAC): The landscape of cancer genes and mutational processes in breast cancer. Nature 486: 400-404, 2012.

3. Negrini M, Nicoloso MS and Calin GA: MicroRNAs and cancer - new paradigms in molecular oncology. Curr Opin Cell Biol 21: 470-479, 2009.

4. Garzon R, Calin GA and Croce CM: MicroRNAs in cancer. Annu Rev Med 60: 167-179, 2009.

5. Calin GA and Croce CM: MicroRNA signatures in human cancers. Nat Rev Cancer 6: 857-866, 2006.

6. Esquela-Kerscher A and Slack FJ: Oncomirs - microRNAs with a role in cancer. Nat Rev Cancer 6: 259-269, 2006.

7. Bartel DP: MicroRNAs: Target recognition and regulatory functions. Cell 136: 215-233, 2009.

8. Cimmino A, Calin GA, Fabbri M, Iorio MV, Ferracin M, Shimizu M, Wojcik SE, Aqeilan RI, Zupo S, Dono M, et al: miR-15 and miR-16 induce apoptosis by targeting BCL2. Proc Natl Acad Sci USA 102: 13944-13949, 2005.

9. Fang L, Deng Z, Shatseva T, Yang J, Peng C, Du WW, Yee AJ, Ang LC, He C, Shan SW and Yang BB: MicroRNA miR-93 promotes tumor growth and angiogenesis by targeting integrin- $\beta 8$. Oncogene 30: 806-821, 2011.

10. Díaz-López A, Moreno-Bueno G and Cano A: Role of microRNA in epithelial to mesenchymal transition and metastasis and clinical perspectives. Cancer Manag Res 6: 205-216, 2014.

11. Chen CZ, Li L, Lodish HF and Bartel DP: MicroRNAs modulate hematopoietic lineage differentiation. Science 303: 83-86, 2004.

12. Braun CJ, Zhang X, Savelyeva I, Wolff S, Moll UM, Schepeler T, Ørntoft TF, Andersen CL and Dobbelstein M: p53-Responsive micrornas 192 and 215 are capable of inducing cell cycle arrest. Cancer Res 68: 10094-10104, 2008.

13. Calin GA, Sevignani C, Dumitru CD, Hyslop T, Noch E, Yendamuri S, Shimizu M, Rattan S, Bullrich F, Negrini M and Croce CM: Human microRNA genes are frequently located at fragile sites and genomic regions involved in cancers. Proc Natl Acad Sci USA 101: 2999-3004, 2004.

14. Lu J, Getz G, Miska EA, Alvarez-Saavedra E, Lamb J, Peck D, Sweet-Cordero A, Ebert BL, Mak RH, Ferrando AA, et al: MicroRNA expression profiles classify human cancers. Nature 435: 834-838, 2005.

15. Volinia S, Calin GA, Liu CG, Ambs S, Cimmino A, Petrocca F, Visone R, Iorio M, Roldo C, Ferracin M, et al: A microRNA expression signature of human solid tumors defines cancer gene targets. Proc Natl Acad Sci USA 103: 2257-2261, 2006.

16. Calin GA, Ferracin M,Cimmino A, Di Leva G, Shimizu M, Wojcik SE, Iorio MV, Visone R, Sever NI, Fabbri M, et al: A MicroRNA signature associated with prognosis and progression in chronic lymphocytic leukemia. N Engl J Med 353: 1793-1801, 2005.

17. Grayson M: Breast cancer. Nature 485: S49, 2012.

18. Byler S, Goldgar S, Heerboth S, Leary M, Housman G, Moulton K and Sarkar S: Genetic and epigenetic aspects of breast cancer progression and therapy. Anticancer Res 34: 1071-1077, 2014.

19. Zhang S, Shan C, Kong G, Du Y, Ye L and Zhang X: MicroRNA-520e suppresses growth of hepatoma cells by targeting the NF- $\kappa \mathrm{B}$-inducing kinase (NIK). Oncogene 31: 3607-3620, 2012

20. Lakhani SR, Elis IO, Schnitt SJ, Tan PH and van de Vijver MJ: WHO Classification of Tumours of the Breast. 4th Edition. IARC, Lyon, pp19-20, 2012.

21. Lim LP, Lau NC, Garrett-Engele P, Grimson A, Schelter JM, Castle J, Bartel DP, Linsley PS and Johnson JM: Microarray analysis shows that some microRNAs downregulate large numbers of target mRNAs. Nature 433: 769-773, 2005.

22. Iorio MV, Ferracin M, Liu CG, Veronese A, Spizzo R, Sabbioni S, Magri E, Pedriali M, Fabbri M, Campiglio M, et al: MicroRNA gene expression deregulation in human breast cancer. Cancer Res 65: 7065-7070, 2005.

23. Liu J, Mao Q, Liu Y, Hao X, Zhang S and Zhang J: Analysis of miR-205 and miR-155 expression in the blood of breast cancer patients. Chin J Cancer Res 25: 46-54, 2013.

24. Yan X, Chen X, Liang H, Deng T, Chen W, Zhang S, Liu M, Gao X, Liu Y,Zhao C, et al: miR-143 and miR-145 synergistically regulate ERBB3 to suppress cell proliferation and invasion in breast cancer. Mol Cancer 13: 220, 2014.

25. Achari C, Winslow S, Ceder Y and Larsson C: Expression of miR-34c induces $\mathrm{G} 2 / \mathrm{M}$ cell cycle arrest in breast cancer cells. BMC Cancer 14: 538, 2014. 
26. Chao CH, Chang CC, Wu MJ, Ko HW, Wang D, Hung MC, Yang JY and Chang CJ: MicroRNA-205 signaling regulates mammary stem cell fate and tumorigenesis. J Clin Invest 124: 3093-3106, 2014

27. Feliciano A, Castellvi J, Artero-Castro A, Leal JA, Romagosa C, Hernández-Losa J, Peg V, Fabra A, Vidal F, Kondoh H, et al: miR-125b acts as a tumor suppressor in breast tumorigenesis via its novel direct targets ENPEP, CK2- $\alpha$, CCNJ, and MEGF9. PLoS One 8: e76247, 2013.

28. Hanahan D and Weinberg RA: Hallmarks of cancer: The next generation. Cell 144: 646-674, 2011.

29. Talmadge JE and Fidler IJ: AACR centennial series: The biology of cancer metastasis: Historical perspective. Cancer Res 70 : 5649-5669, 2010.
30. Ma L: Role of miR-10b in breast cancer metastasis. Breast Cancer Res 12: 210, 2010.

31. Ma L, Teruya-Feldstein J and Weinberg RA: Tumour invasion and metastasis initiated by microRNA-10b in breast cancer. Nature 449: 682-688, 2007.

32. Song B, Wang C, Liu J, Wang X, Lv L, Wei L, Xie L, Zheng Y and Song X: MicroRNA-21 regulates breast cancer invasion partly by targeting tissue inhibitor of metalloproteinase 3 expression. J Exp Clin Cancer Res 29: 29, 2010.

33. Burk U, Schubert J, Wellner U, Schmalhofer O, Vincan E, Spaderna $\mathrm{S}$ and Brabletz T: A reciprocal repression between ZEB1 and members of the miR-200 family promotes EMT and invasion in cancer cells. EMBO Rep 9: 582-589, 2008. 